Info Artikel:

\title{
TEACHING VOCABULARY MASTERY BY USING SYSTEAMTIC GAME
}

\author{
Zulfikri Betyar Rasuan \\ IAIN Syaikh Abdurrahman Siddik Bangka Belitung \\ zulfikri_br@yahoo.co.id
}

\begin{abstract}
David Wilkins said that without grammar very little can be conveyed, without vocabulary nothing can be conveyed. He added that you can say very little with grammar, but you can say almost anything with words. It means that vocabulary is very important in learning English. For teaching vocabulary, the teacher should use an effective and interesting strategy in teaching vocabulary. The learners will learn and remember the word easily if they are taught by using an effective and interesting strategy by the teacher.
\end{abstract}

\begin{abstract}
Abstrak
David Wilkins mengatakan bahwa tanpa tata bahasa sangat sedikit yang bisa disampaikan, tanpa kosakata tidak ada yang bisa disampaikan. Dia menambahkan bahwa Anda dapat mengatakan sangat sedikit dengan tata bahasa, tetapi Anda dapat mengatakan hampir semua hal dengan kata-kata. Artinya kosa kata sangat penting dalam belajar bahasa Inggris. Untuk mengajar kosa kata, guru harus menggunakan strategi yang efektif dan menarik dalam mengajar kosa kata. Peserta didik akan belajar dan mengingat kata dengan mudah jika mereka diajar dengan menggunakan strategi yang efektif dan menarik oleh guru.
\end{abstract}

Keywords: Teaching, Vocabulary, Systeamtic, Game

\section{A. INTRODUCTION}

English is the foreign language for Indonesian people. It is taught to the students from elementary school up to senior high school even in university education as a subject. This subject has been accepted in Indonesia in line with the government's plan on the nine years basic 
education. One part of English Language that should be learned by student is vocabulary. We have to enrich our vocabulary by searching many kinds of easy or diffucult word,

Traditionally, vocabulary has not been a particular subject for students to learn, but has been taught within lessons of speaking, listening, reading and writing. During the lesson, students use their own vocabulary and are introduced to new words provided by the teacher and classmates which they apply to classroom activities. ${ }^{1}$

The vocabulary is a core component of language proficiency and provides much of the basis for how well learners speak, listen, read, and write. ${ }^{2}$ If the students have less vocabulary, it is hard for them to express what they want to speak, listen, read, and write. Their problem is compounded when they need to produce language. Similar to Scott, He said that "finding the right word to fit the intended meaning is frustrating when their store of words is limited."3 Clearly, vocabulary is very important in learning English because it can influence four skills.

The students should have a great number of vocabulary in case they want to have an ability in learning English skills. Richard and Renandya said that "Language learners who wish to own an ability of fluency in English skills must have a large and adequate vocabulary".

Vocabulary has an important role in learning English. Similar to Nattinger, he said that "vocabulary is one of the linguistic components that must be involved in learning English. Each student must acquire the vocabulary by his own. To gain vocabulary mastery, one should deal with comprehension of vocabulary that permits him/her to understand words and store them, to commit the memory." ${ }^{5}$ It is believed that if the students have already understood words, store the words, and committed the words, they can remember and they have many words in their mind.

In addition, Dupuis et al state that "vocabulary is the set of words of phrases which label the parts of the material to be learned and which are necessary for the students to use in talking and writing about the material." ${ }^{\prime 6}$ It means that, vocabulary is needed by students to use in talking and writing. Vocabulary is acquired incidentally through indirect exposure to words and intentionally

${ }^{1}$ Thi, Nguyen. Thanh \& KhuatThi Thu Nga. 2003. Learning Vocabulary through Games; The Effectiveness of Learning Vocabulary Through Games. http://asian-efl journal, Retrieved onJune 26, 2009. www.asian-efl journal.com/dec.03.vn.pdf.

${ }^{2}$ J. Richards and Renandya, W, Methodology........., p. 255.

${ }^{3}$ Scott Thornbury, How to Teach Vocabulary (New York; Longman, 2002),p. 2.

${ }^{4}$ J. Richards and Renandya, W. Methodology in Language Teaching, An Anthology of Current Practice, (New York: Cambridge University Press, 2002), p. 255.

${ }^{5}$ James Nattinger, Vocabulary and Language teaching, Some Current Trends in Vocabulary Teaching, (London; Longman, 1988), p.82.

${ }^{6}$ Mary Dupuis et al, Teaching Reading and Writing in the Content Areas, (London; Scott Foresman \&Company, 1989), p.68. 
through explicit instruction in specifics words and word-learning strategy. According to Graves, "there are four components of an affective vocabulary program": 7

1. Wide or extensive independent reading to expand word knowledge.

2. Instruction in specific words to enhance comprehension of texts containing those words.

3. Instruction in independent word-learning strategies.

4. Word consciousness and word-play activities to motivate the enhance learning.

Based on the statement above, the students should expand their word knowledge by using wide or extensive independent reading. For motivating the enhance learning, the students used independent word-learning strategies, word consciousness and word-play activities.

\section{A. Teaching Vocabulary}

There are some definitions of teaching. Hornby said that "teaching is process of giving knowledge to someone that will cause him to know or to be able to do something". ${ }^{8}$ Besides, Newton said that "teaching is skill for demands the ability attained from relevant theories and practice to assist the students expertly in learning so that they are able to gain linguistic and communicative competence in the target language". ${ }^{9}$ From the definition above, the point, teaching is the process of giving knowledge to someone or students in learning so that they are able to know or to do something in the target language.

In the past, vocabulary teaching and learning were often given little priority in second language programs, but recently there has been a renewed interest in the nature of vocabulary and its role in learning and teaching. Thus, although the course curriculum was often quite specific about aspects of teaching such as grammar, reading, or speaking, little specification was given to the role of vocabulary. ${ }^{10}$ Hunt and Beglar discuss three approaches to vocabulary teaching and learning;

1. Incidental learning (i.e., learning vocabulary as a by-product of doing other things such as reading or listening),

2. Explicit instruction,

3. Independent strategy development.

${ }^{7}$ Michael F. Graves, A Vocabulary Program to Complement and Bolster a Middle-Grade Comprehension Program, (New York; Teachers College Press, 2000), p.15.

${ }^{8}$ Albert Sydney Hornby, Oxford Advanced Learner's Dictionary Current English. (London; Oxford University press, 1995), p.103.

9 John Newton, The Historical Content of Newton's Third Law and Teaching of Mechanics. (Rets University of New South Wales, 1992), p.2.

10 J. Richards and Renandya, W, Methodology........., p. 255 
A major source of incidental learning is extensive reading, which they recommended as a regular out-of-class activity. Explicit instruction depends on identifying specific vocabulary acquisition targets for learners. They stated that there are seven teaching principles for vocabulary development by combining the three approaches;

1. Incidental Learning

a. Principle I: Provide Opportunities for The Incidental Learning of Vocabulary. The incidental learning of vocabulary through extensive reading can benefit language curricula and learners at all levels. The role of graded readers is to build up the students' vocabulary and structures until they can graduate to more authentic materials. Low-proficiency learners can benefit from graded readers because they will be repeatedly exposed to high frequency vocabulary.

2. Explicit Instruction

a. Principle 2: Diagnose Which of The 3.000 Most Common Words Learners Need to Study

Knowing approximately 3.000 high frequency and general academic words is significant because this amount covers a high percentage of the words on an average page. One way to estimate vocabulary size is to use Nation's Vocabulary levels Test or a checklist test which requires learners to mark the words on a list that they believe they know.

b. Principle 3: Provide Opportunities for The Intentional Learning of Vocabulary The incidental learning of vocabulary may eventually account for a majority of a advance learners' vocabulary; however, intentional learning through instruction also significantly contributes to vocabulary development. Explicit instruction is essential for beginning students whose lack of vocabulary limits their reading ability.

c. Principle 4: Provide Opportunities for Elaborating Word Knowledge

Elaborating involves expanding the connections between what the learners already know and new information. In addition to presenting this new information, teachers should create opportunities to meet these useful, recently learned words in new context that provide new collection and associations. Exercises that can deepen students' knowledge of words include the following: sorting lists of words include the following: sorting lists of words and deciding on the categories; making semantic maps with lists either provided by the teacher or generated by the learners; generating derivatives, inflections, synonyms, and antonyms of a word; making trees that show the relationships between superordinates, coordinates, and specific examples; identifying or generating associated words; combining phrases from several columns; matching parts of collocations using two columns; 
completing collocations as a cloze activity; and playing collocation crossword puzzles or bingo.

d. Principle 5: Provide Opportunities for Developing Fluency With Known Vocabulary

Fluency-building activities recycle already known words in familiar grammatical and organizational patterns so that students can focus on recognizing or using words without hesitation. As Nation points out, developing fluency overlaps most of all with developing the skills of listening, speaking, reading, and writing, so giving learners many opportunities to practice these skills is essential.

3. Independent Strategy Development

a. Principle 6: Experiment With Guessing From Context

Guessing from context is a complex and often difficult strategy to carry out successfully. To guess successfully from context, learners need to know about 19 out of every 20 words of a text, which requires knowing the 3,000 most common words. Even if one knows these words, however, Kelly concludes that "useless the context is very constrained, which is a relatively rare occurrence, or unless there is a relationship with a known word identifiable on the basis of form and supported by context, there is a little chance of guessing the correct meaning. Guessing word from context is initially time-consuming and is more likely to work for more proficiency learners. Once learners decide that a word is worth guessing, they might follow a five-step procedure such as that of Nationn and Coady;

1. Determine the part of speech of the unknown word.

2. Look at the immediate context and simplify it if necessary.

3. Look at the wide context. This entails examining the clause with the unknown word and its relationship to the surrounding clauses and sentences.

4. Guess the meaning of unknown word.

5. Check the guess is correct.

b. Principle 7: Examine Different Types of Dictionaries and Teach Students How to Use Them

Bilingual dictionaries have been found to result in vocabulary learning. It may be much more likely to help lower-proficiency learners in reading comprehension because their lack of vocabulary can be a significant factor in their inability to read. Bilingualized dictionaries may have some advantages over traditional bilingual or monolingual dictionaries. Those essentially do the job of both a bilingual and a monolingual dictionary. Moreover, training in the use of 
dictionaries is essential. Unfortunately, in most classrooms, very little time is provided for training in dictionary use.

Teaching vocabulary should be interesting and enjoyable for the students. It is intended in order to the students get easy to keep the new words in their mind. In this case, English teachers should use good strategy in teaching vocabulary to learners. Richard said that "without an extensive vocabulary and strategies for acquiring new vocabulary, learners often achieve less than their potential". 11

Gordon states that "teaching vocabulary should include" 12 :

1. Materials that are motivating to the students

2. Sample exercise

3. Several strategies for unlocking the meaning of words

4. Ways of showing students how to remember what they have learned.

5. Carefully sequenced lessons that will give the students a sense of mastery and progress.

6. Material that present words.

Based on Gordon statement, the writer concluded that his statement is the kinds of thing should be included in material vocabulary that will be taught. In addition, Saleh describes, "the principles of the teaching of vocabulary as follows" $" 13$ :

1. Concrete word, word with meaning that can be perceived the five senses are easier to teach and to learn than abstract word.

2. Vocabulary should always be presented in context, simple sentences in familiar structure.

3. Idioms, like look for and make up should be taught as single units.

4. The learners should be taught and practiced in how to use the dictionary and always be encouraged to use it.

Rubin states that "teachers also help awaken and advance their awareness in student by helping them acquire the tool in addition to the dictionary to expand their vocabulary". ${ }^{14}$ In order that the students can learn and acquire the new vocabulary items which later may be used in their communication, the teacher should present them in such a way that they can be easily understood by the learners.

\footnotetext{
${ }^{11}$ J. Richards and Renandya, W, Methodology....., p. 256.

${ }^{12}$ Carter Gordon, Applied Linguistics, (New York; Applention Century Grofis, Inc, 1991), p.5.

13 Yuslizal Saleh, Techniques for Teaching English as Foreign Language, Palembang : Faculry Teacher Training and Education, 1991), p.24.

14 Dorothy Rubin, Power Vocabulary 1: Basic Word Strategies for Adults, (New Jersey; Pearson Prentice Hall, 1992), p.246.
} 
Vocabulary lists can be an effective way to quickly learn word-pair translations. However, it is more effective to use vocabulary cards because learners can control the order in which they study the words. ${ }^{15}$ Also additional information can easily be added to the cards. When teaching unfamiliar words, teachers have to consider the following: ${ }^{16}$

1. Learners need to know more than just see the form. They need to hear the pronunciation and practice saying the words aloud as well. The syllable structure and stress pattern of the word are important because they are two ways in which words are stored in memory.

2. Start by leaning semantically unrelated words. Also avoid learning words with similar forms and closely related meanings at the same time. For instance, affect and effect have similar forms, simultaneously studying them is likely to cause confusion. Also, bilingual vocabulary books often simply list words in alphabetic order, increasing the chances of confusing the words that start with the same syllable. Likewise, words with similar, opposite, or closely associated meanings may interfere with another if they are studied at the same time.

3. It is more effective to study words regularly over several short sessions than to study them for one or two longer sessions. As most forgetting occurs immediately after initial exposure to the word, repetition and review should take place almost immediately after studying a word for the first time.

4. Study five to seven words at a time, dividing larger numbers of words into smaller groups. As learners review these five to seven cards, they will more quickly get repeated exposure to the words than when larger groups (twenty or thirty) are studied.

5. Use activities such as the keywords technique to promote deeper mental processing and better retention. Associating a visual image with a word helps learners remember that word.

6. A wide variety of second language information can be added to the cards for further elaboration. Newly met words can be consciously associated with other second language words that the learner already knows, and this word can be added to the card. Sentence examples, parts of speech, definitions, and keyword images can also be added.

Moreover, learners need to be taught strategies for inferring words from context as well as those which can help learners retain the meaning of words they have encountered. ${ }^{17}$ Once new

\footnotetext{
15 Jack C. Richards and Willy A. Renandya, Methodology....., p.260.

${ }^{16}$ Jack C. Richards and Willy A. Renandya, Methodology......, p.260-261.

17 Jack C. Richards and Willy A. Renandya, Methodology......, p.256.
} 
words are introduced, students must be encouraged to use these words as often as possible. When they are encountered in print, the words should be noted and shared. The learning circle is closed when students recognize and discuss words in print that they had been introduced in class. ${ }^{18}$

In addition, Saleh states that "a new vocabulary items can be presented by means of props, reality, pictures, demonstration, known words (circumlocution), or translation." 19

\section{Using props}

The teacher can present a new word by means of classroom objects such as duster, dustbin, chalk, etc. The teacher shows the object, like; this is a duster. Then he can present another classroom object in the same way.

\section{Using pictures}

The teacher can introduce words that cannot be taught by props or reality through pictures, such as airplane, boat, kinds of animal, etc. the reason is that it is quiet impossible for the teacher to bring the reality into the classroom. However the pictures must be clear and big enough for whole class to see.

\section{Using demonstrations}

The teacher can make us demonstration to present action verb or some adjectives.

\section{Using known words}

Known words refer to words that the learner have known or been familiar with. Some new words can be taught by using these known words. There are four parts of using known words:

\section{a) Synonyms and antonyms out of context}

- A synonym of often is frequently.

- The opposite of sweet is sour.

\section{b) Synonyms and antonyms in sentence context}

This part is using the new words in sentences that contain a synonym and antonym, for example;

- Rifandi is worn out. Ana is also tired.

- Santi is lazy but her sister Ana is industrious. She works all the time.

\section{c) Categories}

A tiger is an animal, a bear is an animal, a lion is an animal, and an ant is also animal. What are some other examples of animal?

${ }^{18}$ Jane Feber, Active World Play; Games and Activities that Build Vocabulary, (Gainesville; Maupin House, 2008), p.ix.

${ }^{19}$ Yuslizal Saleh, Techniques......, p.24. 


\section{d) Definitions and paraphrases}

Definitions refer to the meaning stated by means of statement of an idea in other way, for instance, a butcher is a person who sells meat or a carpenter is a person who makes furniture.

From statements above, the teacher can use known words as material in applying matching game. The teacher can take synonym and antonym out of context that is presented in the class.

\section{DISCUSSION}

\section{A. Kinds of Vocabulary}

Vocabulary is obviously necessary for four language skills as well. Anyone who uses a language well has a number of different abilities, in the most general way, we can classify for major skills as listening, speaking, reading and speaking.

In learning a foreign language, vocabulary plays an important role. It is one element that links the four skills of speaking, listening, reading and writing all together. In order to communicate well in a foreign language, students should acquire an adequate number of words and should know how to use them accurately. ${ }^{20}$ Besides Feber state that vocabulary is the cornerstone of reading and writing. He added that students who are deficient in vocabulary often struggle with understanding what they read, which causes them to fall behind in content-area subjects, too. Success in school and the ability to acquire vocabulary are powerful reciprocals. ${ }^{21}$ If students are adequate in vocabulary, they will struggle for understanding what they read.

There are many classifications made by the experts in language area about the kinds of vocabulary. Thornbury explained that, "there are six kinds of vocabulary, word classes, word families, word formation, multi-word units, collocations and homonyms.",22

\section{a. Word Classes}

This term belongs to morphology and syntax session, for instance, verb, noun, pronoun, adjective, adverb, preposition, determiner and conjunction

\section{b. Word Families}

Word families almost like word classes. It still belongs to morphology and syntax session. The differences in this term discussed about suffixes in words. Such as play - plays - played $=$ inflected and play - replay - playful $=$ derivatives.

${ }^{20}$ Thi, Nguyen. Thanh\&KhuatThi Thu Nga. 2003. Learning Vocabulary through Games; The Effectiveness of Learning Vocabulary Through Games. http://asian-efl journal, Retrieved onJune 26, 2009. www.asian-efl journal.com/dec.03.vn.pdf

${ }^{21}$ Jane Feber, Active , p.vii.

22 Scott Thorbury, How to Teach........, p. 30 


\section{c. Word Formation}

In English there are some formation of word such as compounding, blending and clipping. For example second hand and typewriter belongs to compounding, information + entertainment $=$ infotainment belongs to blending and electronic mail become email of influenza become flu in clipping.

\section{d. Multi-word Units}

Mostly, this type belongs to phrasal verbs and idioms. For instance, Look for, look after, wipe off, and throw on: phrasal verbs and famous last word, eat your words, jack me around: idioms.

\section{e. Collocations}

This part can be translated as two words or more become together. Such as, this week, once more, once again, as well and so on.

\section{f. Homonyms}

Homonyms are words which have same form but the meaning is different. Such as the word "well" means in bahasa sumur, baik and sehat.

Besides, Cheek, Rona and Jimmy said that, "there are three kinds of vocabulary that may be encountered by the reader in their reading, they are general vocabulary, specialized vocabulary and technical vocabulary". 23

\section{a. High frequency vocabulary}

This group consists of words that are used very often in normal language, use in all four skills and across the full range of situation of use. High frequency vocabulary consists of 2000 word families, which are about $87 \%$ of the running words in formal written text and more than $95 \%$ of the words in informal spoken texts.

\section{b. The low frequency vocabulary}

On the other hand, this group covers only small proportion of the running words of a continuous text, it means that low frequency vocabulary is rarely, used in common activity of English language. This group includes well over 100.000 words families.

From the explanation above, we know that every expert in every book is different in classifying the kinds of vocabulary, because every person has different way in showing and telling their opinions and ideas. Some of them who emphasize vocabulary to the items which the learners can use appropriately in speaking or writing and to the language items that can be recognized and understood in the context of reading and listening and some of them classify vocabulary that they

${ }^{23}$ Earl H. Cheek, Jr., Rona F. Flippo, Jimmy D. Lindsey, Reading for Success in Elementary Schools, (Florida; Holt, Rinehart and Winston, Inc., 1989), p. 113 
have made are different, but the point is the same, because their classification are based on the different sides and aspects.

It can conclude that vocabulary contains two kinds of group, function and content word. Function words these are called grammatical words and content words are usually nouns, verbs, adjectives and adverbs. Furthermore, the writer concludes that there are two kinds of vocabulary used by people for their communication, general and special vocabulary. The general vocabulary is the words used in general; there is no limit of fields or users, general in meaning and use. And the special vocabulary is used in certain field, job, profession or special science. For instance: politicians, journalist and lawyer. All these have specialized vocabulary arising from particular circumstances of their lives and work.

Based on the curriculum applied at State junior and Senior High School, the students learnt about word classes, such as adjective, preposition, noun, adverb, pronoun, conjunction, determiner, verb and irregular verb.

\section{B. Vocabulary Mastery}

This section presents the explanation of vocabulary, mastery and vocabulary mastery.

\section{a. Vocabulary}

Many experts defined the term of vocabulary in many ways. In general, all of the definitions have similar idea that is number of words used for communication.

Hornby stated that "vocabulary is total number of words which (with rules for combining them) make up a language." 24 In other source, Longman said that "vocabulary is a list of words, usually in alphabetically order and with explanations of their meanings." ${ }^{25}$ Webster stated that "vocabulary is a list or collecting of words or of words and phrases usually aphabetically arranged and explained or defined." $26 \mathrm{He}$ also stated that vocabulary is a summary or stock of words employed by a language, group, individual, or work, or in relation to be a subject.

Based on the definition above, it can conclude that vocabulary is the knowledge of words and word meanings. In other word, vocabulary is the total number of words that has meaning and it is also as the element of language which is used in speaking, listening, reading and writing. So, if we want to master in language, we must do mastery in vocabulary too.

${ }^{24}$ Albert Sydney Hornby, Oxford......, p.221.

25 Longman group, Longman Dictionary of Contemporary English New Edition, (Britain: Longman, 1989), p.242.

${ }^{26}$ Merriam Webster, Webster's Third New International Dictionary of The English Language Unabridged, (Massachusetts; Merriam Company, 1966), p.243. 


\section{b. Mastery}

There are some definitions of mastery from some experts. The word mastery means complete knowledge; great skill. From this simple definition, the word mastery is tightly related to the complete knowledge, and great skill of something. Barnhart said that "mastery is a very great skill or knowledge." 27 Besides, Webster said, "mastery is great skill or knowledge in a particular subject or activity. Webster also stated same meaning that mastery is the skill or knowledge in a subject that makes one a master in it." ${ }^{28}$ It means practices not knowledge alone. In this case, mastery is a level of performance shows that a student has demonstrated the knowledge, skill and abilities for a unity of instruction or subject area depend by a recognized standard.

\section{c. Vocabulary Mastery}

Based on the definition in above, it can be concluded that vocabulary mastery is great skill and knowledge of words and meaning in both oral and print language and in productive and receptive form. According to Ur, she stated that "some aspects that the learner should be mastered and should be taught in order to help the learners in mastering vocabulary, namely; Form (pronunciation and spelling), Grammar, Collocation, Aspect of meaning (a. Denotation, connotation, appropriateness and b. Meaning relationship) and Word formation." 29 This skill and those aspects are used for learning English in order to understand the meaning of a great number of vocabulary.

\section{E. Matching Game}

There are so many games for strategy in teaching and learning vocabulary, such as card games, bumper sticker game, bingo game and so forth. Those games will help students learn words in context and use them in new ways. Once students find a strategy that works best for them, encourage them to implement this strategy as they continue to learn new vocabulary. ${ }^{30}$ The game strategy must relate to the age of students that would be taught. The game strategy can support learning vocabulary and one of the interesting strategies. Furthermore, the game can give the students a challenge to play while learning. In this case, the writer would use 'matching game' as a strategy in improving students' vocabulary.

${ }^{27}$ Thorndike Barnhart, Intermediate Dictionary, (New Jersey: Scott Foresman, 1997), p.255.

${ }^{28}$ Merriam Webster, Webster's........, p. 123

29 Penny Ur,. A Course in Language Teaching: Practice and Theory. (Cambridge: Cambridge University Press, 1998),p. 60-62.

${ }^{30}$ Jane Feber, Active World Play (Games and Activities that Build Vocabulary), (Gainesville: Maupin House, 2008), p. ix 
'Moreover, Wright said that "games encourage, entertain, teach, and promote fluency. If not for any of these reasons, they should be used just because they help students see the beauty in a foreign language." 31 Therefore, the role of games in teaching and learning vocabulary is undeniable. However, in order to achieve the goal of learning from vocabulary games, it is essential that suitable games are chosen. According to Nguyen, "whenever a game is to be conducted, the number of students, teenager level, cultural context, timing, learning topic, and the classroom settings are factors that should be taken into account." 32 That is why 'matching game' should be suitable with the level of student and the kinds of vocabulary itself.

Generally, if the teacher used game as strategy for teaching, that game should have some benefits that student should take. McCallum says that "games automatically stimulate the student's interest. Games can be one of the highest motivating techniques." ${ }^{33}$ Similar to Lee, He said that "games are enjoyable, there is communicative aspect to this activity, games therefore should not be regarded as a marginal activity, feeling in odd moments when the teacher and class have nothing better to do." 34 Those are the benefits of using games in teaching English, especially for vocabulary. It can be concluded that games is one of the highest motivating techniques and enjoyable in teaching activity.

As we know, matching game belongs to word play that can give a positive contribution in language learning. We know that different combination of words gives different meanings. Hornby defines, "a word is a sound or combination of sounds (written or printed symbols), forming a unit of a grammar of vocabulary of a language." ${ }^{35}$ In other words, there is no communication if there is no word, and it can be concluded that words take an important part in language. Langan says that "the students with strong vocabulary are more successful in school than those whose vocabulary is limited." ${ }^{, 36}$ In other words, the more words a learner has the greater his/her chance to success in English communication.

31 Andrew Wright, David Betteridge and Michael Buckby, 'Games for Language Learning' (2nd. Ed.) (Cambridge: Cambridge University Press, 1984), p. 21.

32 Thi, Nguyen. Thanh\&KhuatThi Thu Nga. 2003. Learning Vocabulary through Games; The Effectiveness of Learning Vocabulary Through Games. http://asian-efl journal, Retrieved onJune 26, 2009. www.asian-efl journal.com/dec.03.vn.pdf.

${ }^{33}$ George P. McCallum, 101 Words Game for Students of English as a Second or Foreign Language, (New York; Oxford University press,1980), p.ix.

34 William Rowland Lee, Language Teaching Games and Contest, (Oxford; Oxford University Press, 1979), p.1.

${ }^{35}$ Albert Sydney Hornby, Oxford....., p.91.

${ }^{36}$ John Langan, Improving Vocabulary Skills, (New York; Townsend press, 1991), p, 37. 
There are two types of games communicative and linguistic game. Hadfield explains two ways of classifying language games. First, she divides language games into two types: linguistic games and communicative games. Linguistic games focus on accuracy, such as supplying the correct antonym. On the other hand, communicative games focus on successful exchange of information and ideas, such as two people identifying the differences between their two pictures which are similar to one another but not exactly alike. Correct language usage, though still important, is secondary to achieving the communicative goal.

In the matching game, students play with vocabulary and morpheme cards to test their knowledge and memory. In pairs or small groups, students place their cards face down individually on a smooth surface. One at a time, each student turns over two cards with the goal of findings a word-definition match. The winner of the game is the student who finds the most matches. ${ }^{37}$ Moreover, Hadfield states that "matching games, as the name implies, participants need to find a match for a word, picture, or card. For example, students place 30 word cards, composed of 15 pairs, face down in random order. Each person turns over two cards at a time, with the goal of turning over a matching pair, by using their memory ${ }^{33}$.

This game is an effective way to practice the target vocabulary or grammar is to create a matching activity that asks students to match vocabulary and grammar items to corresponding words, images, or even sounds representing them. ${ }^{39}$ Match words belongs to matching game. Matching game used word in a card and the procedure of teaching that writer's applying is almost same with Hadfield's example, but the difference is before students match some words they got explanation from the teacher about the meaning of every word. After that they would remember what the teacher had explained.

For this game, the writer chose card as a media in matching game, student matched word to word, word meaning or word roots. First thing that must be done is preparing the material, Davies explained that "some steps that must be prepared in matching game" 40 :

1. Copy card stock game cards and answer key cards if multiple copies of the same game are needed.

2. Pull out the colored card stock game cards. Separate the pieces along perforated lines.

${ }^{37}$ Jane Feber, Active World Play; Games and Activities that Build Vocabulary, (Gainesville; Maupin House, 2008), p.5.

${ }^{38}$ Hadfield, "Using Games in Language Teaching”, http://Theory_of_games_in_teaching_vocabulary.com, accessed on February 20"th 2012.

39 Tatiana Gordon, Teaching Young Children a Second Language, (London; Preager Publisher, 2007), p.193.

${ }^{40}$ Steven J. Davis, Vocabulary Matching Games that Reinforce Standard-based Language Skill, (California; Creative Teaching Press, 2010), p.4. 
3. Laminate the answer key cards and the game cards for durability.

4. Attach the answer key card to a sandwich-size re-sealable plastic bag or small manila envelope, and place the game cards inside.

5. Store the games in a plastic or cardboard shoe box.

After the teacher prepared the material, the teacher should know the way of game play and direction itself. For game play, this game just need 1-3 players or students. The objectives of this game are ${ }^{41}$

1. 1 player: Match all pairs of cards in the fewest number of turns

2. 2-3 players: Find the most pairs of matching cards.

antonym, synonym or root words and word-meaning as vocabulary material that would be taught. From this game, students are provided practice in the following skill: ${ }^{42}$

a. Identifying words that have similar meanings (synonym) and words that have opposite meaning (antonym)

b. Recognizing that words can sound alike but have different meanings (homophones)

c. Identifying base words and common prefixes and suffixes to determine the meaning of words

d. Identifying and explaining the defining characteristics of literacy genres, language, and elements

e. Identifying appropriate informal materials to use for given situations.

\section{CONCLUSION}

Teaching and learning vocabulary through games is one effective and interesting ways that can be applied in any classrooms, especially by using matching game. The result of this writing suggests that games are used not only for mere fun, but more importantly, for the useful practice and review of language lessons, thus leading toward the goal of improving learners' vocabulary mastery. Although games is one of effective and interesting strategy in teaching vocabulary, games have some disadvantages, such as using games in the classroom sometimes fails due to the lack of cooperation among members of the class; games require all students' involvement and they promote friendly competition, therefore, it is very important that students have a cooperative attitude; and another issue that related to using games for language teaching, students usually speak in their mother tongue to discuss instead of the language they are learning. Moreover, games cannot be successful if the teacher does not explain the tasks and roles of students clearly in

\footnotetext{
${ }^{41}$ Steven J. Davis, Vocabulary ............., p.4

${ }^{42}$ Steven J. Davies, Matching games.........., p.3.
} 
playing games. For solving the disadvantages of game, teacher should control the whole class, check during the students play the game, or gives clearly explanation about the procedure of game.

\section{References}

Barnhart, Thorndike. 1997. Intermediate Dictionary. New Jersey: Scott Foresman.

Cheek, Earl H Jr., Rona F. Flippo, Jimmy D. Lindsey. 1989. Reading for Success in Elementary Schools. Florida: Holt, Rinehart and Winston, Inc.

Davies, Steven J. 2010. Vocabulary Matching Games that Reinforce Standard-based Language Skill. California: Creative Teaching Press.

Dupuis, Mary. 1989 Teaching Reading and Writing in the Content Areas. London: Scott Foresman \& Company.

Feber, Jane. 2008. Active World Play (Games and Activities that Build Vocabulary). Gainesville: Maupin House.

Gordon, Carter. 1991. Applied Linguistics. New York: Applention Century Grofis, Inc.

Gordon, Tatiana. 2007. Teaching Young Children a Second Language. London; Preager Publisher.

Graves, Michael F. 2000. A Vocabulary Program to Complement and Bolster a Middle-Grade Comprehension Program. New York: Teachers College Press.

Hadfield, "Using Games in Language Teaching", http://Theory _of_games_in_teaching_vocabulary.com, accessed on February $20^{\text {th }}, 2012$.

Hornby, Albert Sydney. 1995. Oxford Advanced Learner's Dictionary Current English. London: Oxford University press.

Langan, John. 1991. Improving Vocabulary Skills. New York: Townsend press.

Lee, William Rowland. 1979. Language Teaching Games and Contest. Oxford: Oxford University Press.

Longman group. 1989. Longman Dictionary of Contemporary English New Edition. Britain: Longman.

McCallum, George P. 1980. 101 Words Game for Students of English as a Second or Foreign Language. New York: Oxford University press.

Nation, Paul. 1994. New Way of Teaching Vocabulary. New York: Teacher of English to Speaker of Another Language/TESOL inc.

Nattinger, James. 1988. Vocabulary and Language teaching, Some Current Trends in Vocabulary Teaching. London: Longman. 
Newton, John.1992. The Historical Content of Newton's Third Law and Teaching of Mechanics. Rets University of New South Wales.

Richards, Jack C. and Renandya, W. 2002. Methodology in Language Teaching, An Anthology of Current Practice. New York: Cambridge University Press.

Rubin, Dorothy. 1992. Power Vocabulary 1: Basic Word Strategies for Adults. New Jersey: Pearson Prentice Hall.

Saleh, Yuslizal.1991. Techniques for Teaching English as Foreign Language, Palembang: Faculry Teacher Training and Education.

Thornbury, Scott.2002 How to Teach Vocabulary. New York: Longman.

Ur, Penny. 1998. A Course in Language Teaching: Practice and Theory. Cambridge: Cambridge University Press.

Webster, Merriam. 1966. Webster's Third New International Dictionary of the English Language Unabridged. Massachusetts: Merriam Company.

Wright, Andrew, David Betteridge and Michael Buckby. 'Games for Language Learning' (2nd. $E d$.). Cambridge: Cambridge University Press. 